\title{
Fusion Protein
}

National Cancer Institute

\section{Source}

National Cancer Institute. Fusion Protein. NCI Thesaurus. Code C17561.

A protein in which the coding region of two genes have become in-frame and cocontinuous. Fusion proteins can be formed by chromosomal breakage and/or recombination and also can be experimentally created using recombinant DNA techniques. 